\title{
THE EFFECT OF DIFFERENT LEVELS OF OLIVE OIL ON HEPATIC RATS
}

\author{
By \\ Dr/Lobna Saad Mohamed Abd El- meged \\ Associate Prof. of Nutrition and Food Science, Home \\ Economics (nutrition) Dept., Faculty of Science \& \\ Arts,Al-Baha University
}

Research Gournal Specific Fducation

Faculty of Specific Education

gMansoura University

ISSUE NO. 35, JULY. 2014

مجلة بحوث التربية النوعية - جامعة المنصورة

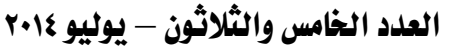




\section{THE EFFECT OF DIFFERENT LEVELS OF OLIVE OIL ON HEPATIC RATS}

\section{Dr/Lobna Saad Mohamed Abd El- meged*}

\section{Abstract}

These research aimed to determine the effect of different levels of olive oil on mice infected with the liver. The study used 24 adult male albino rats, weight $170 \pm 10 \mathrm{gm}$. All mice were fed on a normal diet for four consecutive days. Then the rats were divided into six groups, each with 4 mice. All groups of mice were fed the experimental diet for 4 weeks with the exception of the negative control group, which was fed to the main meal. Mice were injected with experimental groups carbon tetrachloride mixed with paraffin oil to liver injury mice were then taking a blood sample to check the incidence of the disease. The results showed an increase significant in the total weight of the mice infected with the liver and which were fed on the 5\%, 10\% olive oil significant $(\mathrm{P}<0.05)$ compared with the control negative . the results also showed a low of significant differences in total cholesterol and LDL between groups 5\%,10\% olive oil and the control group when compared with negative control . finally great significant differences in GPT between the control group and 5\%,10\% olive oil when compared to the control group cationic.

KEYWORDS : Hepatic patient - Liver diseases - Olive oil

\section{Introduction}

The greatest exponent of monounsaturated fat is olive oil, and it is a prime component of the Mediterranean Diet. Olive oil is a natural juice which preserves the taste, aroma, vitamins and properties of the olive fruit. Olive oil is the only vegetable oil that can be consumed as it is - freshly pressed from the fruit. The beneficial health effects of olive oil are due to both its high content of monounsaturated fatty acids and its high content of antioxidative substances. Studies have shown that olive oil offers protection against heart disease by controlling LDL ("bad") cholesterol levels while raising HDL (the "good" cholesterol) levels. (1-3) No other naturally produced oil has as large an amount of monounsaturated as olive oil -mainly oleic acid.( European Journal of Clinical Nutrition , 2002) .Olive oil is very

Associate Prof. of Nutrition and Food Science, Home Economics (nutrition) Dept., Faculty of Science \& Arts,Al-Baha University 
well tolerated by the stomach. In fact, olive oil's protective function has a beneficial effect on ulcers and gastritis. Olive oil activates the secretion of bile and pancreatic hormones much more naturally than prescribed drugs. Consequently, it lowers the incidence of gallstone formation.(World Health Organization, 2006). Studies have shown that people who consumed 25 milliliters (mL) - about 2 tablespoons - of virgin olive oil daily for 1 week showed less oxidation of LDL cholesterol and higher levels of antioxidant compounds, particularly phenols, in the blood.

\section{Aim of study}

The effect of olive oil diets on biochemical changes (serum glucoseserum lipids - liver function - kidney function and some physiological change like weight organs) in hepatic rats

\section{Materials And Methods}

\section{MATERIALS:}

\section{.I ) MATERIALS:}

1- Olive oil : virgin olive oil were obtained from Minufiya University of Faculty of Home Economic

2- Normal male albino rats were obtained from Research institute of Ophthalmology Medical Analysis Department ,Giza, Egypt.

3- Carbon Tetrachloride Ccl4 and paraffin oil: obtained from Minufiya University of Faculty of Home Economics.

4- Casein :casein as main source of protein obtained from El-Gomhoria Company ,Cairo ,Egypt.

\section{Method}

1- preparation olive oil.

2- Drooping of experimental animals (rats).

3- Induction of liver disorder in experimental animals rats..

4- Biological evaluation

5- biochemical analysis.

6- organs weight.

7- Histopathological examination

8- Statistical analysis. 


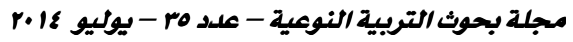

\section{Analytical Methods:}

\section{Chemical Composition.}

- Moisture

- Crude protein was determined using semi micro kjeldahl method according to AOAC (1995).

- Crude fat was determined using Sochelt Apparatus according to AOAC (1995). carbohydrate were calculated by differences :

Carbohydrates $(\%)=100-(\%$ Mositure $+\%$ Protein $+\%$ Fat $+\%$ Ahs + $\%$ Fiber).

\section{Biological Investigation:}

\section{2-1 Experimental Animals:}

twenty fore (24) Sprague-Dawley strain male albino rats, weighting $170 \pm 10 \mathrm{~g}$ were used in this study. All rats were fed the control (casein) diet for 4 consecutive days. Each rat was housed individually in stainless steel wire cage under controlled condition. Diets were introduced to the rats in a special non-scattering feeding cup to avoid loss of food and contamination. Tap water was provided to rats by mean of glass tubes projecting through wire cages from inverted bottles supported to one side of the cage.

\section{2-2 Diets:}

Semi purified diet was prepared from fine ingredient $\mathrm{g} / 100 \mathrm{~g}$. The protein content was added at $12 \%$ level on the expens of starch according to (AIN, 1993) presented in the table (A),salt mixture and vitamins mixture were prepared according to (Hegested et al 1941), and (Campbell 1961) as shown in the table $(b, c)$.

\section{2-3 Induced Disease for rats:}

\section{Preparation of hepatic rats:}

Carbon tetra chloride mixed with paraffin oil used as toxic chemical for liver injury according to the method described by (pass more, east wood, 1986), then fasting blood serum were obtained and levels of Got, Gpt and Alp investigated.

All groups of rats were fed the experimental diet for 4 weeks according to the following groups: 
First group: (normal rats):

Group 1: control group (control negative) - five rats were fed basal diet for 28 days.

\section{Second group: (hepatic rats)}

Group 1 : rats fed on basal diet only as the control positive

Group 2 : rats fed an basal diet containing 5\% olive oil.

Group 3 : rats fed on basal diet containing $10 \%$ olive oil.

Group 4 : rats fed on basal diet and oral, $0.25 \% \mathrm{ml}$ of olive oil.

Group 5 : rats fed on basal diet and oral $0.5 \% \mathrm{ml}$ olive oil.

\section{Blood sampling:}

Blood samples were collected after 12 hour fasting at the end of the experiment. Using the retro - orbital method by means of a micro capillary glass tubes, blood was collected into a dry clean centrifuge tube and left to clot in a water bath $\left(37^{\circ} \mathrm{C}\right)$ at room temperature for half an hour. The blood was centrifuged for 10 minutes at 3000 r.p.m. to separate the serum a part of was subjected to glucose determination and the reminder was carefully aspirated and transferred into clean quit fit plastic tubes and kept frozen at ($20^{\circ} \mathrm{C}$ ) until analysis. The organs (liver, kidney, heart, and spleen) were removed and washed in saline solution, weighted and kept in formalin solution (10\%) according to methods described by Drury and Wallington (1980).

\section{Biological evaluation:}

Food intake (consumption), body weight gain\% (BWG \%), feed efficiency ratio (FER) according to Chapman et al., (1959).

\section{Biochemical analysis:}

1) Determination of serum glucose: serum glucose was determined using chemical kits according (Trinder, 1969).

2) Determination of serum lipids:

\section{1) Triglycerides:}

Enzymatic calorimetric determination of Triglycerides was carried out according to Fassati and Prencipe (1982). 


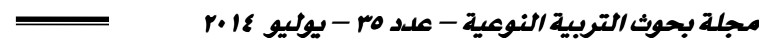

\section{2) Total cholesterol:}

The principle use of total cholesterol determination according to Allain, (1974).

\section{3) HDL-cholesterol:}

- Principle:

Phosphotungstic acid and magnesium ions selectivity precipitating all lipoproteins except the HDL fraction-cholesterol present in the supernatant can be determined by the same method used for total cholesterol, according to Lopez, (1977).

\section{4) V-LDL and LDL-cholesterol:}

The determination of VLDL (very low density lipoprotins) and LDL were carried out according to the method of Lee and Nieman (1996)

\section{5)Total Lipids :}

Total lipids was determined by colorimetric method (according to schmit 1964)

\section{Determination of liver functions:}

\section{1) Determination of Alanine transferase (ALT):}

Determination of (ALT) was carried out according to the method of Tietz (1976).

ALT catalyzes the transfer of the amino group from L-alanine to aKetoglutarate resulting in the formation of pyruvate and L-Glutamate ..

\section{2) Determination of Asartate Transferase (AST):}

Determination of (AST) was carried out according to the method of Henry (1974) and Yound (1975).

\section{3) Determination of Total Protein:}

Total protein was measured according to the colorimetric method of Henry (1964), by following reaction:- 
_ The effect of different levels of olive oil on hepatic rats

\section{Determination of Some parameters for:}

\section{1) Determination of Creatinine} (1974),

Creatinine was determined according to kinetic method of Henry

\section{2) Determination of urea:}

Urea was determined according to the enzymatic method of Patton and Crouch (1977),

\section{3). Uric acid:}

- Organs weight :

After taking retro orbital blood samples, each rat was rapidly opened, the organs ( liver, kidney, heart, spleen, lungs, brain) were removed and washed in saline soluation, weighed and kept in formalin solution (10\% V/V) according to methods described by Drury and Wallington (1980), then compared to control group .

\section{- Histopathological examination :}

Specimens from liver, kidney and heart were collected directly after scarificzed of animals at the end of experimental period, fixed in $10 \%$ neutral formalin, dehydrated in ethyl alcohol, cleared in xylene and embedded in paraffin wax 4-6 thick sections were prepared and stained with hemetoxlin and eosin (Carleton,1978)

\section{Statistical Analysis:}

Statistical analysis were calculated using one way classification. Analysis of variance (ANOVA), and least significant difference (LSD) according to (Snedcor and Cochran 1967).

\section{Results and Discussion}

\section{1) Chemical Results}

\section{Chemical composition of olive oil:}

The chemical composition of olive oil was analyzed for their contents of moisture, ash, protein, fat, fiber, carbohydrates. The obtained results are presented in the table (1). Data of table (1) showed the chemical composition of olive oil . It is clear that, results of moisture content for olive oil was $(0.0 \%)$. In addition ash content for olive oil was $(0.0)$. In the same 
table it is worthy to notice that protein $(0.0 \%)$, total fat , saturated fat , mono un saturated fat , poly un saturated fat $(100 \%, 14 \%, 73 \%, 11 \%)$ respectively. Furthermore fiber and carbohydrate contents for olive oil were $(0.0 \&$ $0.0 \%$ ), respectively. These results were agree with (Arief Budiyanto et al 2000). shwed that olive oil has more uses than just consuming, it also works as a natural and safe lubricant. For example, lubricating the machinery that is used within the kitchen (grinders, blenders, cookware, etc.)

Table (1) : Chemical composition of olive oil (On Dry) Weight Basis :

\begin{tabular}{|c|c||}
\hline Parameter Samples & Constiluents g/100 gm \\
\hline \hline Moisture (\%) & 0.0 \\
\hline Ash (\%) & 0.0 \\
\hline Protein (\%) & 0.0 \\
\hline Total Fat (\%) & 100 \\
\hline Saturated Fat & 14.0 \\
\hline Monounsaturated Fat & 72.0 \\
\hline Polyunsaturated Fat & 12.0 \\
\hline fiber (\%) & 0.0 \\
\hline Carbohydrate (\%) & 0.0 \\
\hline
\end{tabular}

\section{2) Biological results:}

\section{1) Effect of olive oil on liver treated groups with Feeding Olive Oil (5\% and $10 \%$ ).}

Effect of olive oil on Body weight gain (BWG\%)of change on liver disorder rat- Data in table (2) indicate Body weight gain in both normal and liver disorder rats after 4 weeks of feeding. Body weight gain in normal rats group was $(52.4 \pm 11.46) \mathrm{gm} / 100 \mathrm{gm}$. While liver disorder rats groups fed a diet at different levels (positive control , 5\%, and 10\% olive oil) showed an increase . Body weight gain (35.9 \pm 10.58$),(63.1 \pm 8.68)$, and $(70.1 \pm 7.37)$ $\mathrm{gm} / 100 \mathrm{gm}$, respectively. the results showed that all groups were significantly higher $(\mathrm{P}<0.05)$ when compared with control negative Feed efficiency ratio (fer)values in normal rats group was $(0.19 \pm 0.03)$. While in liver disorder rats groups fed a diet at different levels of olive oil were $(0.304 \pm 0.22,0.252 \pm 0.03$, and $0.27 \pm 0.02$,$) . the result showed that non$ significant in all group when compared with control negative. Food intake Feed efficiency ratio value in normal rats group was $(48.8 \pm 31.86)$ 
$\mathrm{gm} / 100 \mathrm{gm}$.While in liver disorder rats group fed diet different levels of olive oil (positive control, 5\%, and 10\%)showed that (503.6 \pm 7.5 , $443.6 \pm 7.73$, and $453.4 \pm 37.24) \mathrm{gm} / 100 \mathrm{gm}$, respectively the results showed non significant between groups $(5 \%$ and $10 \%)$ olive oil $(\mathrm{P}<0.05)$ when compared with control negative .

Table(2): Effect of different levels of olive oil on Body weight gain (BWG\%),

Food intake (FI) (g/28day), and Feed efficiency ratio (FER) in hepatic rats,

\begin{tabular}{|c|c|c|c|c|c|c|}
\hline Groups & Control (-) & Control (+) & $5 \%$ olive oil & $10 \%$ olive oil & \multirow[t]{2}{*}{ Sig } & \multirow{2}{*}{ LSD } \\
\hline Parameters & Mean + SD & Mean + SD & Mean + SD & Mean + SD & & \\
\hline $\begin{array}{l}\text { Body weight } \\
\text { gain (bwg\%) }\end{array}$ & $52.4 b+11.4$ & $35.9 c+10.5$ & $63.1 \mathrm{ab}+8.68$ & $70.1 a+7.37$ & $*$ & 13.045 \\
\hline $\begin{array}{l}\text { Food intake } \\
\text { (fi)(g/28day) }\end{array}$ & $478.8 \mathrm{ab}+31.8$ & $503.6 a+7.5$ & $443.6 b+7.73$ & $453.4 b+37.2$ & NS & 0.153 \\
\hline $\begin{array}{l}\text { Feed efficiency } \\
\text { ratio (fer) }\end{array}$ & $0.19 a+0.03$ & $0.304 a+0.2$ & $0.252 a+0.03$ & $0.27 a+0.02$ & $*$ & 33.639 \\
\hline
\end{tabular}

Data in table (3) indicates the effect of level olive oil on organ weight and organ weight /body weight in both normal and liver disorder rats after 4 weeks of feeding. The liver in normal rats group was $(2.34 \pm 0.15) \mathrm{gm} / 100 \mathrm{gm}$. While liver disorder rats groups fed a diet at different level of olive oil (positive control , 5\%, and 10\%olive oil) showed an decrease relative weight of liver $(3.008 \pm 0.23),(3.12 \pm 0.46)$, and $(2.78 \pm 0.38) \mathrm{gm} / 100 \mathrm{gm}$, respectively. the results showed that non significant in all groups Relative kidney weight values in normal rats group was $(0.646 \pm 0.05)$. While in liver disorder rats groups fed a diet at different levels of olive oil were $(0.65 \pm 0.05$ $, 0.56 \pm 0.02$, and $0.52 \pm 0.07)$. the result showed that group of $5 \%$ and $10 \%$ olive oil were significantly increase $(\mathrm{P}<0.05)$ when compared with control negative. While non significant between control positive and control negative . Relative heart weight value in normal rats group was $(0.318 \pm 0.013) \mathrm{gm} / 100 \mathrm{gm}$.While liver disorder rats group fed diet different levels of olive oil (positive control, 10\%, 15\% , and 20\%)showed that $(0.34 \pm 0.02,00.29 \pm 0.01$, and $0.28 \pm 0.03$ ) gm/100gm , respectively the results showed that non significant between $5 \%$ and $10 \%$ olive oil . Relative lung weight values in normal rats group was $(0.55 \pm 0.08)$. While in liver disorder rats groups fed a diet at different levels of olive oil were $(0.5 \pm 0.05$, $0.58 \pm 0.11$, and $0.57 \pm 0.11$ ). the result showed non significant between all groups. Relative spleen $t$ weight value in normal rats group was $(0.45 \pm 0.1)$ $\mathrm{gm} / 100 \mathrm{gm}$. While liver disorder rats group fed diet different levels of olive oil (positive control, 10\%, 15\% , and 20\%)showed that $(0.46 \pm 0.01$, 
$0.55 \pm 0.04$, and $0.47 \pm 0.12) \mathrm{gm} / 100 \mathrm{gm}$, respectively the results showed that non significant between all groups .

Table(3): Effect of different levels of olive oil on Relative Weight in hepatic rats

\begin{tabular}{||c|c|c|c|c|c|c||}
\hline \multirow{2}{*}{$\begin{array}{c}\text { Groups } \\
\text { Parameters }\end{array}$} & Control (-) & Control (+) & $5 \%$ olive oil & $10 \%$ olive oil & \multirow{2}{*}{ sig } & \multirow{2}{*}{ LSD } \\
\cline { 2 - 7 } & Mean + SD & Mean + SD & Mean + SD & Mean +SD & & \\
\hline \hline LUNG & $0.55 \mathrm{a}+0.08$ & $0.5 \mathrm{a}+0.05$ & $0.58 \mathrm{a}+0.11$ & $0.57 \mathrm{a}+0.11$ & $\mathrm{NS}$ & 0.122 \\
\hline LIVER & $2.78 \mathrm{a}+0.38$ & $2.34 \mathrm{a}+0.15$ & $3.008 \mathrm{a}+0.23$ & $3.12 \mathrm{a}+0.46$ & NS & 0.883 \\
\hline HEART & $0.318 \mathrm{a}+0.013$ & $0.34 \mathrm{a}+0.02$ & $00.29 \mathrm{~b}+0.01$ & $0.28 \mathrm{~b}+0.03$ & $*$ & 0.027 \\
\hline KIDNEY & $0.646 \mathrm{a}+0.05$ & $0.65 \mathrm{a}+0.05$ & $0.56 \mathrm{ab}+0.02$ & $0.52 \mathrm{~b}+0.07$ & $*$ & 0.069 \\
\hline SPLEEN & $0.45 \mathrm{a}+0.1$ & $0.46 \mathrm{a}+0.01$ & $0.55 \mathrm{a}+0.04$ & $0.47 \mathrm{a}+0.12$ & $\mathrm{NS}$ & 0.127 \\
\hline \hline
\end{tabular}

Table (4) represent the effect of feeding different levels of olive oil on T.Lipids, PH.Lipids, and T-Cholesterol, in both normal and liver disorder rats after 4 weeks of feeding. The total Lipids in normal rats group was $(237.6 \pm 10.5) \mathrm{mg} / \mathrm{dl}$. While liver disorder rats groups fed supplement diet at different levels (positive control, 5\%, and10\% olive oil) showed total Lipids values $(277.4 \pm 3.71,243.2 \pm 1.79$, and $233 \pm 2.24) \mathrm{mg} / \mathrm{dl}$ respectively . PH.Lipids values in normal rate group was $(101.6 \pm 2.3) \mathrm{mmol} / \mathrm{L}$.While in liver disorder rats groups fed a diet with different levels of olive oil were $(107.8 \pm 0.45),(105.2 \pm 0.45)$, and $(105.4 \pm 0.9) \mathrm{mg} / \mathrm{dl}$ at levels (positive control, $5 \%$, and $10 \%) \mathrm{mg} / \mathrm{dl}$, respectively.

The effect of different levels of olive oil on total Lipids and Ph.Lipids in table (9) concerning serum total Lipids the results showed that all groups were significantly more $(\mathrm{P}<0.05)$ when compared with control negative . Also Ph.Lipids showed that rats fed on $10 \%$ olive oil was non significant $(\mathrm{P}<0.05)$ when compared with control negative .Cholesterol values in normal rate group was $(81.6 \pm 5.13) \mathrm{mmol} / \mathrm{L}$. While in liver disorder rats groups fed a diet with different levels of olive oil were $(101.8 \pm 3.03)$ ,(85.4 \pm 0.89$)$, and $(78.4 \pm 2.19) \mathrm{mg} / \mathrm{dl}$ at levels (positive control, $5 \%$, and $10 \%) \mathrm{mg} / \mathrm{dl}$, respectively. Lipids showed that rats fed on $10 \%$ olive oil was high significantly $(\mathrm{P}<0.05)$ when compared with control positive. The present results are going in the same line with (Ichihashi, et al 2000) suggests that a higher proportion of monounsaturated fats in the diet is linked with a reduction in the risk of coronary heart disease. This is significant because olive oil is considerably rich in monounsaturated fats, most notably oleic acid. in the United States, producers of olive oil may 
place the following health claim on product labels: limited and not conclusive scientific evidence suggests that eating about 2 tbsp. (23 g) of olive oil daily may reduce the risk of coronary heart disease due to the monounsaturated fat in olive oil. To achieve this possible benefit, olive oil is to replace a similar amount of saturated fat and not increase the total number of calories you eat in a day.

Table(4): Effect of different levels of olive oil on T.Lipids , PH.Lipids and Cholesterol in hepatic rats

\begin{tabular}{|c|c|c|c|c|c|c||}
\hline \multirow{2}{*}{ Groups } & C- & $\mathrm{C}+$ & $5 \%$ olive oil & $10 \%$ olive oil & \multirow{2}{*}{ sig } & \multirow{2}{*}{ LSD } \\
\cline { 2 - 8 } & Mean + SD & Mean + SD & Mean + SD & Mean + SD & & \\
\hline \hline T.LIPIDS & $237.6 \mathrm{bc}+10.5$ & $277.4 \mathrm{a}+3.71$ & $243.2 \mathrm{~b}+1.79$ & $233 \mathrm{c}+2.24$ & $*$ & 7.173 \\
\hline PH.LIPIDS & $101.6 \mathrm{c}+2.3$ & $107.8 \mathrm{a}+0.45$ & $105.2 \mathrm{~b}+0.45$ & $105.4 \mathrm{~b}+0.9$ & $*$ & 1.709 \\
\hline CHOLESTEROL & $81.6 \mathrm{bc}+5.13$ & $101.8 \mathrm{a}+3.03$ & $85.4 \mathrm{~b}+0.89$ & $78.4 \mathrm{c}+2.19$ & $*$ & 4.297 \\
\hline
\end{tabular}

Table (5) represent the effect of feeding different levels of olive oil on T.G, HDL, LDL , and VLDL in both normal and liver disorder rats after 4 weeks of feeding. The T.G in normal rats group was $(53.2 \pm 5.85) \mathrm{mg} / \mathrm{dl}$. While liver disorder rats groups fed supplement diet at different levels (positive control, 5\%, and10\% olive oil) showed T.G values $(68.2 \pm 1.3$, $518 \pm 2.68$, and $48.4 \pm 0.89) \mathrm{mg} / \mathrm{dl}$ respectively. HDL values in normal rate group was $(46 \pm 1.41) \mathrm{mmol} / \mathrm{L}$. While in liver disorder rats groups fed a diet with different levels of olive oil were $(42.4 \pm 0.56),(45.8 \pm 0.56)$, and $(45.2 \pm 1.09) \mathrm{mg} / \mathrm{dl}$ at levels (positive control, $5 \%$, and $10 \%) \mathrm{mg} / \mathrm{dl}$, respectively.the result showed that non significant differences between 5\% , $10 \%$ olive oil and control negative when comperd with control positive .LDL values in normal rate group was $(26.56 \pm 3.24) \mathrm{mmol} / \mathrm{L}$. While in liver disorder rats groups fed a diet with different levels of olive oil were (54.6 \pm 2.69$),(28.12 \pm 2.69)$, and $(24.28 \pm 1.63) \mathrm{mg} / \mathrm{dl}$ at levels (positive control, $5 \%$, and $10 \%) \mathrm{mg} / \mathrm{dl}$, respectively.groups of $5 \%$ and $10 \%$ olive oil high significantly $(\mathrm{P}<0.05)$ when comperad with control negative. VLDL values in normal rate group was $(10.62 \pm 1.17) \mathrm{mmol} / \mathrm{L}$. While in liver disorder rats groups fed a diet with different levels of olive oil were $(13.44 \pm 0.7),(10.63 \pm 054)$, and $(9.68 \pm 0.18) \mathrm{mg} / \mathrm{dl}$ at levels (positive control, $5 \%$, and $10 \%) \mathrm{mg} / \mathrm{dl}$, respectively. The result showed non significant differences between 5\%,10\% and control negative when compard with control positive .The present results are going in the same line with (Mangas et al 2001). showed that rats fed olive oil enriched with the non-fatty acid components had greater beneficial effects on HLD "good" cholesterol than did those fed ordinary virgin olive oil, or oil enriched with Oleic acid. 
Table(5): Effect of different levels of olive oil on T.G, HDL, LDL and VLDL in hepatic rats.

\begin{tabular}{|c|c|c|c|c|c|c||}
\hline Groups & Control (-) & Control (+) & 5\% olive oil & $10 \%$ olive oil & \multirow{2}{*}{ sig } & \multirow{2}{*}{ LSD } \\
\cline { 2 - 8 } Parameters & Mean + SD & Mean + SD & Mean + SD & Mean + SD & & \\
\hline \hline T.G & $53.2 \mathrm{~b}+5.85$ & $68.2 \mathrm{a}+1.3$ & $51.8 \mathrm{~b}+2.68$ & $48.4 \mathrm{~b}+0.89$ & $*$ & 4.441 \\
\hline HDL & $46 \mathrm{a}+1.41$ & $42.4 \mathrm{~b}+0.56$ & $45.8 \mathrm{a}+0.45$ & $45.2 \mathrm{a}+1.09$ & $\mathrm{NS}$ & 1.289 \\
\hline LDL & $26.56 \mathrm{c}+3.2$ & $54.6 \mathrm{a}+2.69$ & $28.12 \mathrm{~b}+1.4$ & $24.48 \mathrm{c}+1.6$ & $*$ & 3.175 \\
\hline VLDL & $10.62 \mathrm{~b}+1.1$ & $13.44 \mathrm{a}+0.7$ & $10.36 \mathrm{~b}+0.5$ & $9.68 \mathrm{~b}+0.18$ & $*$ & 0.988 \\
\hline
\end{tabular}

Table (6) reflects the effect of different level of olive oil on creatinine, urea and uric acid values in both normal and liver dis order rats fed diet with different level of olive oil . urea values recorded $(27.6 \pm 4.77) \mathrm{mg} / 100 \mathrm{ml}$ in normal rats group. While liver disorder rats fed olive oil at values (positive control , 5\% and $10 \%)$ showed serum urea levels $(30 \pm 2.83,37 \pm 4.12$, and $27.6 \pm 1.34) \mathrm{mg} / 100 \mathrm{ml}$, respectively. As for urea the results revealed that non significant in all groups. Accorded to the same table normal rats group recorded serum creatinin level $(0.598 \pm 0.07) \mathrm{mg} / 100 \mathrm{ml}$. While olive oil supplemented with different levels to the diet were (positive control, 5\% ,and $10 \%$,) presented the values $(0.6 \pm 0.007,0.68 \pm 0.02$, and $0.644 \pm 0.03$ )mg/100ml, respectively . the results showed that significantly higher $(\mathrm{P}<0.05)$ between $5 \%$ and $10 \%$ olive oil when compared with control negative. Also in the same table normal rats group recorded U.acid level $(1.68 \pm 0.39) \mathrm{mg} / 100 \mathrm{ml}$. While olive oil supplemented with different levels to the diet were (positive control, 5\%, and 10\%,) presented the values $(1.5 \pm 0.07,1.1 \pm 0.14$, and $1.9 \pm 0.17) \mathrm{mg} / 100 \mathrm{ml}$, respectively the result showed that high significantly in all groups $(\mathrm{P}<0.05)$

Table(6): Effect of different levels of olive oil on renal Functions in hepatic rats.

\begin{tabular}{||c|c|c|c|c|c|c||}
\hline \multirow{2}{*}{$\begin{array}{c}\text { Groups } \\
\text { Parameters }\end{array}$} & Control (-) & Control $(+)$ & $5 \%$ olive oil & $10 \%$ olive oil & \multirow{2}{*}{ sig } & \multirow{2}{*}{ LSD } \\
\cline { 2 - 7 } & Mean + SD & Mean + SD & Mean + SD & Mean + SD & & \\
\hline \hline UREA & $27.6 \mathrm{a}+4.77$ & $30 \mathrm{a}+2.83$ & $37 \mathrm{a}+4.12$ & $27.6 \mathrm{a}+1.34$ & NS & 4.721 \\
\hline CREATININ & $0.598 \mathrm{~b}+0.07$ & $0.6 \mathrm{~b}+0.007$ & $0.68 \mathrm{a}+0.02$ & $0.644 \mathrm{~b}+0.03$ & $*$ & 0.054 \\
\hline U.ACID & $1.68 \mathrm{ab}+0.39$ & $1.5 \mathrm{~b}+0.07$ & $1.1 \mathrm{c}+0.14$ & $1.9 \mathrm{a}+0.17$ & $*$ & 0.305 \\
\hline \hline
\end{tabular}

Table (7) revealed the effect of olive oil on enzymes activity (.GOT, GPT , and ALP ) on both normal and liver disorder rats groups . GOT level in normal rats group was $(94.8 \pm 6.61) \mathrm{u} / \mathrm{l}$. while liver disorder rats groups were fed diet containing (positive control, $5 \%$ and $10 \%$ olive oil ) recorded (178.4 \pm 11.26$),(99.8 \pm 1.3)$ and $(90.4 \pm 2.19) \mathrm{u} / 1$, respectively. Normal rats group represented GPT level $(42.8 \pm 3.89)$ u/l .While liver disorder rats groups were fed a diet supplemented with olive oil containing (positive 
control, 5\% , and 10\% ) showed a values $(73.4 \pm 7.16,42.6 \pm 3.58$, and $40.2 \pm 1.79) \mathrm{u} / \mathrm{l}$. With regard to table 10 for enzymes activity normal rats

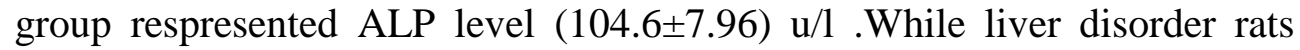
groups were fed a diet supplemented with olive oil containing (positive control, 5\% , and 10\% )showed a values (116.8 \pm 2.17$),(105 \pm 4.47)$ and $(105 \pm 3.08) \mathrm{u} / 1$. The results showed that non significant differences between control negative, $5 \%$, and $10 \%$ olive oil when compared with control positive .Our finding is in accordance with (Takeuci Hisanao et al 2001), The effects of dietary oils on stress-induced changes in the liver glycogen metabolism of male Wistar rats at 6 weeks of age were investigated.

Table(7) Effect of different levels of olive oil on Some Liver Functions in hepatic rats

\begin{tabular}{||c|c|c|c|c|c|c||}
\hline \multirow{2}{*}{ Groups } & Control (-) & Control (+) & $5 \%$ olive oil & $10 \%$ olive oil & \multirow{2}{*}{ Sig } & \multirow{2}{*}{ LSD } \\
\cline { 2 - 7 } & Mean + SD & Mean + SD & Mean + SD & Mean + SD & & \\
\hline \hline GOT & $94.8 \mathrm{~b}+6.61$ & $178.4 \mathrm{a}+11.26$ & $99.8 \mathrm{~b}+1.3$ & $90.4 \mathrm{~b}+2.19$ & $*$ & 8.919 \\
\hline GPT & $42.8 \mathrm{~b}+3.89$ & $73.4 \mathrm{a}+7.16$ & $42.6 \mathrm{~b}+3.58$ & $40.2 \mathrm{~b}+1.79$ & $*$ & 6.088 \\
\hline ALP & $104.6 \mathrm{~b}+7.96$ & $116.8 \mathrm{a}+3.02$ & $105 \mathrm{~b}+4.47$ & $105 \mathrm{~b}+3.08$ & $*$ & 8.770 \\
\hline
\end{tabular}

Table (8) revealed the effect of olive oil on enzymes activity (T.PRO, ALB, GLOB, BLIL.T , and BILID ) on both normal and liver disorder rats groups . T.PRO level in normal rats group was $(5.69 \pm 0.23) \mathrm{u} / \mathrm{l}$. while liver disorder rats groups were fed diet containing (positive control, 5\% and 10\% olive oil ) recorded $(5.71 \pm 0.09),(5.97 \pm 0.16)$ and $(5.65 \pm 0.26) \mathrm{u} / \mathrm{l}$, respectively. Normal rats group represented ALB level $(3.78 \pm 0.07) \mathrm{u} / \mathrm{l}$.While liver disorder rats groups were fed a diet supplemented with olive oil containing (positive control, 5\%, and 10\%) showed a values $(3.79 \pm 0.05,3.69 \pm 0.19$, and $3.90 \pm 013) \mathrm{u} / \mathrm{l}$. With regard to table 10 for enzymes activity normal rats group respresented GLOB level $(1.87 \pm 0.023) \mathrm{u} / 1$.While liver disorder rats groups were fed a diet supplemented with olive oil containing (positive control, 5\% , and 10\% )showed a values (1.99 \pm 0.07$),(2.28 \pm 0.03)$ and $(1.74 \pm 0.21) \mathrm{u} / \mathrm{l}$. The results showed that non significant differences between $5 \%$, and $10 \%$ olive oil when compared with control positive. Normal rats group represented BLIL.T level $(0.402 \pm 0.02) \mathrm{u} / \mathrm{l}$.While liver disorder rats groups were fed a diet supplemented with olive oil containing (positive control, $5 \%$, and $10 \%$ ) showed a values $(0.428 \pm 0.02,0.376 \pm 0.04$, and $0.396 \pm 0.01) \mathrm{u} / 1$.With regard to table 10 for enzymes activity normal rats group respresented BILI.D level $(0.13 \pm 0.02) \mathrm{u} / \mathrm{l}$.While liver disorder rats groups were fed a diet supplemented with olive oil containing (positive control, 5\%, and 10\% )showed a values $(1.48 \pm 0.02),(0.126 \pm 0.02)$ and 
$(0.116 \pm 0.008) \mathrm{u} / \mathrm{l}$. The results showed that non significant differences between all groups.

Table(8) Effect of different levels of olive oil on Some Liver Functions in hepatic rats.

\begin{tabular}{||c|c|c|c|c|c|c||}
\hline Groups & Control (-) & Control (+) & 5\% olive oil & 10\% olive oil & \multirow{2}{*}{ sig } & LSD \\
\cline { 2 - 7 } Parameters & Mean + SD & Mean + SD & Mean + SD & Mean +SD & & \\
\hline \hline T.PRO & $5.69 \mathrm{a}+0.23$ & $5.71 \mathrm{a}+0.09$ & $5.97 \mathrm{a}+0.16$ & $5.65 \mathrm{a}+0.26$ & $\mathrm{NS}$ & 0.263 \\
\hline ALB & $3.78 \mathrm{a}+0.07$ & $3.79 \mathrm{a}+0.05$ & $3.69 \mathrm{a}+0.19$ & $3.90 \mathrm{a}+0.13$ & $\mathrm{NS}$ & 0.165 \\
\hline GLOB & $1.87 \mathrm{~b}+0.02$ & $1.99 \mathrm{a}+0.07$ & $2.28 \mathrm{~b}+0.03$ & $1.74 \mathrm{~b}+0.21$ & $*$ & 0.219 \\
\hline BLIL.T & $0.40 \mathrm{ab}+0.02$ & $0.42 \mathrm{a}+0.02$ & $0.37 \mathrm{~b}+0.04$ & $0.39 \mathrm{~b}+0.01$ & $*$ & 0.032 \\
\hline BILI.D & $0.13 \mathrm{a}+0.02$ & $1.48 \mathrm{a}+0.02$ & $0.126 \mathrm{a}+0.02$ & $0.116 \mathrm{a}+0.008$ & $\mathrm{NS}$ & 0.026 \\
\hline
\end{tabular}

\section{REFERENCES}

- A.O.A.C. (1995). Association of Official Agriculture of Chemists. Official Method of Analysis. 18th ed. A.O.A.C., Washington, U.S.A

- AIN,(1993). American Institute Nutrition purified diet for laboratory rodents . Final report . ADHOC writing committee on the reformulation of the AIN . 76A .Rodent diet . J of Nutrition . Vol 123:1939-1951.

- AIN,(1993). American Institute Nutrition purified diet for laboratory rodents . Final report . ADHOC writing committee on the reformulation of the AIN . 76A .Rodent diet . J of Nutrition . Vol 123:1939-1951.

- Al Jawhara Al-Ashrie,(2007). Effect of Olive Oil of Different Qualities on Plasma and Liver Lipids in Rats, J of nutr vol (23) pp235:237.

- Alhazza I. M.(2007). Antioxidant and Hypolipidemic Effects of Olive Oil in Normal and Diabetic Male Rats .Saudi Journal of Biological Sciences 14 (1) 6974.

- Alicia Leikin Frenkel, Lea Canetti and Zamir Halpern (2004). Effects of moderate-fat (from monounsaturated fat) and low-fat weight-loss diets on the serum lipid profile in over weight and obese men, women.The American Journal of Clinical Nutrition, 79, (No2) : 204-212 .

- Alicia Leikin Frenkel, Lea Canetti and Zamir Halpern (2004). The Benefits Of Olive Oil On Diabetes Prevention. The American Journal of Clinical Nutrition, 79, (No2) : 204-212 .

- Allain, C. C, (1974). Cholesterol enzymatic colorimetric method. J. of Clin. Chem., (20):470.

- Allain, C. C, (1974). Cholesterol enzymatic colorimetric method. J. of Clin. Chem., (20):470.

- Amani ,R. Baghdadchi ,J. Zand ,A.(2003). Virgin Olive Oil May Reduce Cholesterol Damage .Nutr Rev.1;1-33. 
- Amani ,R. Baghdadchi „J. Zand ,A.(2003).Effect of soy protein isoflavones on serum lipids, lipoprotein profile and serum glucose of hypercholesterolemic rabbits .Nutr Rev.1;1-33.

- American Diabetes Association,(2002). Health Benefits of Olive Oil. J of nutr, 25(suppl.i):564-568.

- Annals (2006); The Effect of Polyphenols in Olive Oil on Heart Disease Risk Factors - the Eurolive Study Group, of Internal Medicine, Vol 145 number 5, 5 Sept 2006

- Arief Budiyanto, Nazim U. Ahmed, An Wu, Toshinori Bito, Osamu Nikaido, Toshihiko Osawa, Masato Ueda, Masamitsu Ichihashi, (2000). "Protective effect of topically applied olive oil against photocarcinogenesis following UVB exposure of mice", Carcinogenesis, Vol. 21, No. 11, pp. 2085-2090.

- Barnard ,ND ,and ,Colleagues.(2006). Olive Oil and Antioxidants .Diabetes Care, 29:1777-1783.

- Bartoli R, Fernandez-Banares F, Navarro E, Castella E, Mane J, Alvarez M, Pastor C, Cabre E, Gassull MA(2002) ; Olive Oil May Protect Against Colon Cancer. Department of Gastroenterology, Hospital Universitari Germans Trias Pujol, Carretera del Canyet s/n, 08916 Badalona, Spain.

- Ben Miled, A. Smaoui, M. Zarrouk1 and Chérif A.(2000); Do extraction procedures affect olive oil quality and stabilility. Biochem. Soc. Trans. (2000) 28, (929-933)

- Campbell, J. A. (1961). Methodology of Protein Evaluation. RAG Nutr . Document R.10Led. 37. Who ;June Meeting, New York.

- Carleton,H.(1978); Carleton Histopathological Technique, 4 the Ed .london, oxford university press. New York. Toronto.

- Chapman, D. G.; Castilla, R. and Campbell, J. A. (1959).Evaluation of protein in food- I:A method for the determination of protein efficiency ratio. Can. J. Biochem. Physiol., 37:679-686

- Decker EA.(1995). The role of phenolics, conjugated linoleic acid, carnosine, and pyrroloquinoline quinone as non essential dietary antioxidants. Nutr Rev 53: 49-58.

- Durant, and John.(2000). Country of origin marking of imported olive oil. US Customs Department, Director Commercial Rulings Division .vol (21) pp 695;697

- Ehud Galili et al.,(1997). "Evidence for Earliest Olive-Oil Production in Submerged Settlements off the Carmel Coast, Israel", Journal of Archaeological Science 24:1141-1150 (1997); Pagnol, p. 19,

- European Journal of Clinical Nutrition (2002);56:114-120

- Fassati, P. and Prencipe, L. (1982). Triglyceride enzymatic colorimetric method. J. of Clin. Chem., 28: 2077. 
- Ferrara, L. A.; Raimondi, A. S.; d'Episcopo, L.; Guida, L.; Dello, R. A.; Marotta, T.(2000), Olive Oil and Reduced Need for Antihypertensive Medications. Arch. Intern. Med,160, 837-842.

- Fito M, Covas MI, Lamuela-Raventos RM, Vila J, de la Torre C, Marrugat J. (2000); Olive oil and inhibition of low density lipoprotein oxidation. Role of phenolic compounds. Med Clin (Barc).1;115(5):166-9. (Article in Spanish) Unidad de Lipidos y Epidemiologia Cardiovascular, Institut Municipal d'Investigacio Medica (IMIM), Barcelona.

- H, Bachmann K, Mrowietz C, Koscielny J, Wenzel E, Kiesewetter H. (2001) Effects of an onion-olive oil maceration product containing essential ingredients of the Mediterranean diet on blood pressure and blood fluidity.;51(2):104-11. Medizinische Fakultat, Humboldt Universitat Berlin, Institut fur Transfusionsmedizin,

- Hegested, A. (1941). Cholin in checks. J. Biol. Chem., 138:459.

- Henry, R. J. (1974). Clinical Chemist: Principles and Technics, 2nd Edition, Hagerstown (MD), Harcer, Row; 882.

- Ichihashi, M : Ahmed, N U : Budiyanto, A : Wu, A : Bito, T : Ueda, M : Osawa, T,(2000). "Preventive effect of antioxidant on ultraviolet-induced skin cancer in mice. ", J-Dermatol-Sci., Vol. 23, Suppl. 1S45-50, Mar.

- John Deane M.D.(2000) ; Olive Oil is the Healthy Choice for Frying contact Ankara University, Medical Faculty, Department of Biochemistry, Turkey.

- Kirimlioglu V, Kirimlioglu H, Yilmaz S, Ozgor D, Coban S, Karadag N, Yologlu S.(2006). Effect of fish oil, olive oil, and vitamin E on liver pathology, cell proliferation, and antioxidant defense system in rats subjected to partial hepatectomy. 38(2):564-7

- Lee A, Thurnham DI, Chopra M.(2000); Consumption of tomato products with olive oil but not sunflower oil increases the antioxidant activity of plasma. Free Radic Biol Med. 15;29(10):1051-5. Northern Ireland Centre for Diet and Health, School of Biomedical Sciences, University of Ulster, Northern Ireland, Coleraine, UK.

- Lee, R. and Nieman, D. (1996). Nutritional Assessment. 2nd Ed., Mosby, Missouri, 591-594. USA

- Lopez, M.F. (1977). HDL-cholesterol colorimetric method. J. of Clin. Chem, 23:882.

- Mangas-Cruz, M. A.; Fernandez-Moyano, A.; Albi, T.; Guinda, A.; Relimpio, F.; Lanzon, A.; Pereira, J. L.; Serrera, J. L.; Montilla, C.; Astorga, R.; Garcia-Luna, P. P.(2001) Effects of Minor Constituents (Non-Glyceride Compounds) of Virgin Olive Oil on Plasma Lipid Concentrations in Male Wistar Rats. Clin Nutr ,20, 211-215.

- Maria-Isabel Covas ,(2006) The Effect of Polyphenols in Olive Oil on Heart Disease Risk Factors. American journal . Volume 145 Issue 5 Pages 333-341. 
- Martalena-Purba, Antigone , Kouris-Blazos (2001); "Skin Wrinkling: Can Food Make a Difference?" Journal of the American College of Nutrition;20:71-80.

- Martinez-Dominguez E, de la Puerta R, Ruiz-Gutierrez V. Inflamm Res. (2001); Protective effects upon experimental inflammation models of a polyphenolsupplemented virgin olive oil diet;50(2):102-6. Departamento de Farmacologia, Facultad de Farmacia, Universidad de Sevilla, Spain.

- Martinez-Dominguez, E.; Ruiz-Gutierrez, V.(2000). Effect of Minor Components of Virgin Olive Oil on Topical Antiinflammatory Assays.Naturforsch.,55, 814-819.

- Michelle D. Holmes; David J. Hunter; Graham A. Colditz; Meir J. Stampfer; Susan E. Hankinson; Frank E. Speizer; Bernard Rosner; Walter C .(2001); Association of Dietary Intake of Fat and Fatty Acids With Risk of Breast Cancer. Willett JAMA 281: 914-920.

- Nigel and Kennell ,(2001) "Most Necessary for the Bodies of Men: Olive Oil and its By-products in the Later Greek Gymnasium" in Mark Joyal (ed.), In Altum: Seventy-Five Years of Classical Studies in Newfoundland, pp119-33.

- Passmore, R. And Eastwood ,MA(1986) :Human Nutrition and dietetics .Eight edition .Longman Group UK LTD . Churchill livingstone .

- Ramon Aparicio ;(2009): Chemical and Nutritional Properties of Olive Oil. Jof utrvol 22 pp295:300.

- Reprints: L. Aldo Ferrara, MD,(2006) Olive Oil for Blood Pressure Reduction .Department of Clinical and Experimental Medicine, Federico II University of Naples, Via S Pansini 5, 80131, Naples, Italy

- Riley, F.R. (2002), "Olive Oil Production on Bronze Age Crete: Nutritional properties, Processing methods, and Storage life of Minoan olive oil", Oxford Journal of Archaeology 21:1:63-75

- Rocca AS, LaGreca J, Kalitsky J, Brubaker PL.(2001); Monounsaturated fatty acid diets improve glycemic tolerance through increased secretion of glucagonlike peptide;142(3):1148-55. Department of Physiology, University of Toronto, Toronto, Ontario, Canada.

- Rodriguez-Villar C, Manzanares JM, Casals E, Perez-Heras A, Zambon D, Gomis R, Ros E. Metabolism. (2000) High-monounsaturated fat, olive oil-rich diet has effects similar to a high-carbohydrate diet on fasting and postprandial state and metabolic profiles of patients with type 2 diabetes. 49(12):1511-7. Lipid Clinic, Nutrition and Dietetics Service, Institut d'Investigacions Biomediques ,Hospital Clinical Provincial, Barcelona, Spain.

- Sajeev Bhaskar.(2007). olive oil and health. J of nutr, vol 23.pp 625;629.

- Snedecor G.W. and,Cochran.W.G .(1967). Statestical Methods 6th Ed. Ioea Stat University press ames Iowa USA. 
- Solanas M . Int J (2002) ;Effects of a high olive oil diet on the clinical behavior and histopathological features of rat DMBA-induced mammary tumors compared with a high corn oil diet. 21(4): 745-53 Akalin, A.S. Gonç, S. Unal,

- Szende, B : Timar, F : Hargitai, B (1994). Olive oil decreases liver damage in rats caused by carbon tetrachloride (CCl4). Exp-Toxicol-Pathol. 46(4-5): 355-9

- Takeuci Hisanao , Suzuki Norio , tada Masakazu,(2001), Accelerative Effect of Olive Oil on Liver Glycogen Synthesis in Rats Subjected to Water-immersion Restraint Stress(Food \& Nutrition Science) . biochemistry 65(7), 1489-1494 .

- Trevisan; V. Krogh; J. Freudenheim; A. Blake; P. Muti; S. Panico; E. Farinaro; M. Mancini; A. Menotti; G.(2005) Consumption of olive oil, butter, and vegetable oils and coronary heart disease risk factors. The Research Group ATSRF2 of the Italian National Research Council JAMA 263: 688-692. Ricci Universitatsklinikum Charite, Berlin, Germany.

- Trinder, P. (1969). Glucose enzymatic colorimetric method. J. Clin. Biochem.,(6):24.

- Tripoli, M. Giammanco, G. Tabacchi, D. Di Majo, S. Giammanco, and Maurizio La Guardia, (2005). Nutrition Research Reviews 18, 98-112 .

- Turner R, Etienne N, Alonso MG, et al (2005). "Antioxidant and anti-atherogenic activities of olive oil phenolics". Int J Vitam Nutr Res 75 (1): 61-70.

- Visioli F, Caruso D, Plasmati E, Patelli R, Mulinacci N, Romani A, Galli G, Galli C.( 2001)Hydroxytyrosol, as a Component of Olive Mill Waste Water, is Dose- Dependently Absorbed and Increases the Antioxidant Capacity of Rat Plasma;34(3):301-305. Institute of Pharmacological Sciences, University of Milan, Via Balzaretti 9, 20133 Milan.

- Visioli F, Galli C, Plasmati E, Viappiani S, Hernandez A, Colombo C, Sala A.(2000) Olive phenol hydroxytyrosol prevents passive smoking-induced oxidative stress. 31;102(18):2169-71. University of Milan, Institute of Pharmacological Sciences, Milan, Italy.

- Willett WC, (1999): Diet and coronary heart disease. Monographs in Epidemiology and Biostatistics 15: 341-379

- World Health Organization(2006): Diet, nutrition, and the prevention of chronic diseases. Report of a WHO Study Group. WHO Technical Report Series 797. 


\section{تأثير المتتويات المختلفة لزيت الزيتون على الفئران المصابة بالكبد

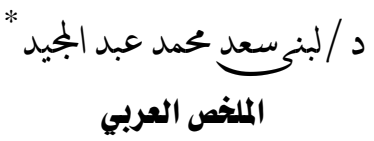

يهـدف البحـث إلى تحديـد تأثير المستويات المختلفـة مـن زيـت الزيتـون على الفئران المصابة

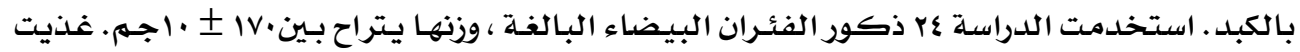

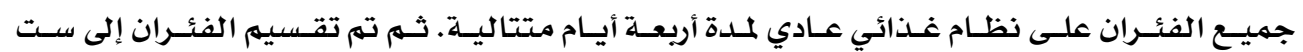

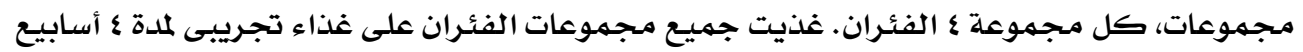

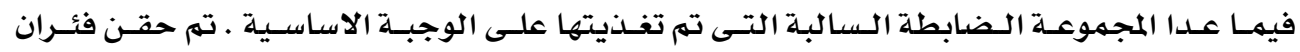

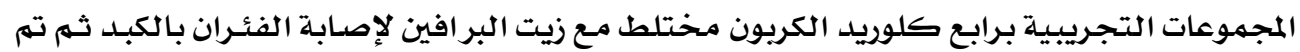

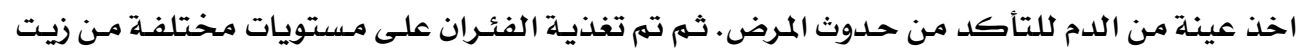

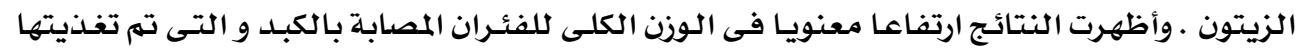

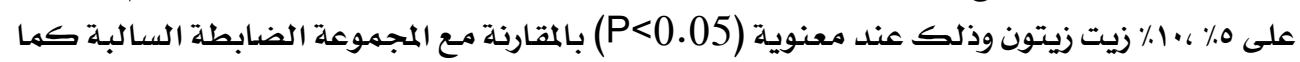

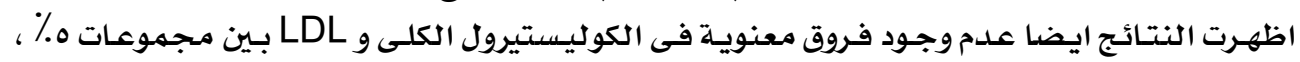

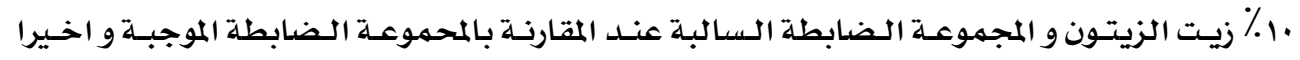

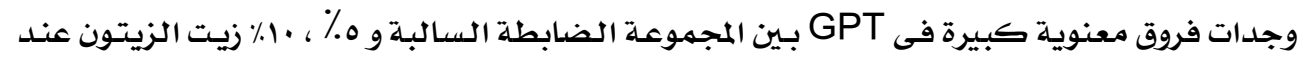

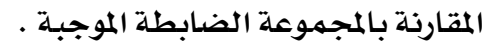
الكلمات المفتاحية : - امراض الكبد - زيته الزيتون - مرضى الكبد 